ИЗВЕСТИЯ АКАДЕМИИ НАУК ЭСТОНСКОЯ ССР. ТОМ 22 ХИМИЯ * ГЕОЛОГИЯ. 1973, № 3

\title{
НОВЫЕ БРАХИОПОДЫ ОRТНАСЕА ИЗ СРЕДНЕГО ОРДОВИКА ПРИБАЛТИКИ И ШВЕЦИИ
}

В настоящей статье описываются новый род и три новых вида брахиопод надсемейства Orthacea. Новые таксоны обнаружены в средне- и верхневируских отложениях (в нижнем карадоке и низах верхнего карадока) главным образом в разрезах Шведско-Латвийской фациальной зоны (рис. 1; см. также Мянниль, 1966, рис. 2). Описываемые брахиоподы имеют определенное сходство с представителями надсемейства Enteletacea по внешним признакам раковины, и поэтому в некоторых страти-

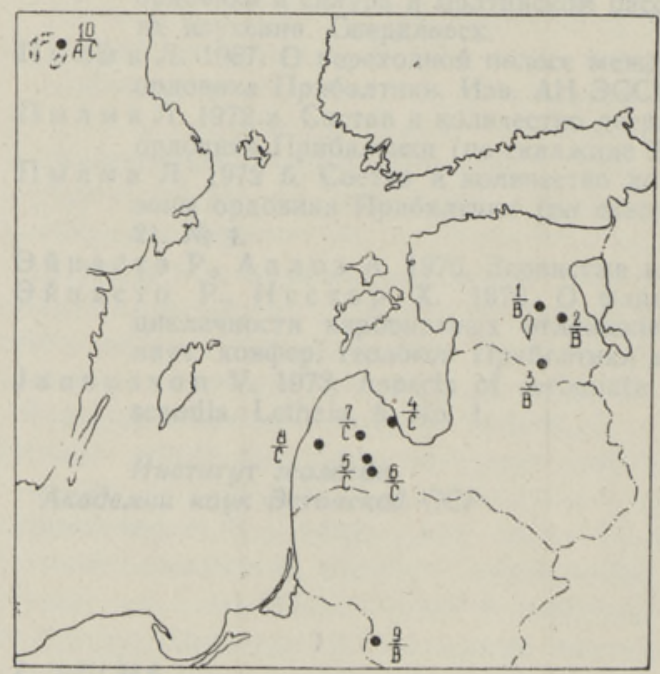

Рис. 1. Схема расположения буровых скважин и обнажений, в которых установлены виды:

A - Taphrorthis dalarnaensis, B - Rhactorthis kaagverensis, C - Septorthis engurensis. Скважнны: 1 - Лаэва, 2 - Каагвере, 3 - Карула, 4 - Энгуре, 5 - Стури, 6 - Ремте, 7 Кандава-25, 8 - Адзе, 9 - Паявонис-13; обнажения: $10-$ № 8 и 9 в окрестностях Фьяка. графических работах часть описываемого здесь материала рассматривалась как Dalmanella cf. navis (Мянниль, 1963, рис. 3) и «Dalmanella» n. sp. (Мянниль, 1966 , рис. 14 и 15$)$.

Автор выражает благодарность доктору В. Яануссону (Стокгольм), любезно предоставившему для изучения коллекцию шведских брахиопод из обнажений в окрестностях Фьяка района оз. Сильян, обозначенных В. Яануссоном как обнажения № 8 и 9 (см. Jaanusson, Martna, 1948, рис. 1; отмеченные обнажения располагаются от обнажения № 7 соответственно к северо-западу и северу).

Описанные в статье прибалтийские экземпляры хранятся в геологическом музее Института геологии АН ЭССР в Таллине (каталоговые номера $\mathrm{Br} 4102$ и т. д.), шведские экземпляры в Музее истории природы в Стокгольме (каталоговые номера Br. 103278 и т. д.). 


\title{
ОПИСАНИЕ БРАХИОПОД
}

\section{Надсемейство Orthacea Woodward, 1852}

\section{Семейство Orthidae Woodward, 1852}

\section{Подсемейство Orthinae Woodward, 1852}

\section{Род Taphrorthis Cooper, 1956}

\author{
Taphrorthis dalarnaensis sp. nov.
}

(Табл. I, фиг. 1-6)

Г ол о ти п. Раковина Br. 103278, табл. I, фиг. 1-4. Макроурусовый известняк, Швеция, Фьяка, обнажение № 9.

Д и а гн о 3. Раковина со слабо выпуклыми створками. Арея брюшной створки высокая. На расстоянии 2 и 5 мм от макушки спинной створки в 2 мм насчитывается соответственно 4 и 8 ребрышек.

О п и с а н и е. Раковина средних размеров, со слабо выпуклыми створками. Очертание овальное, вытянутое в ширину. Замочная линия прямая, короче наибольшей ширины раковины. Замочные углы прямые или тупые. Передняя комиссура ректимаргинатная.

Раковина покрыта тонкими, многократно расщепляющимися ребрышками. По краям раковины насчитывается до 62 ребрышек, из них 13-14 начинаются у протегулума и на заднем крае створки. На расстоянии 2 и 5 мм от макушки спинной створки в 2 мм насчитывается соответственно 4 и 8 ребрышек. Между ребрышками имеется тонкая поперечная струйчатость. Линии нарастания редкие.

Брюшная створка слабо выпуклая, передняя и боковые части уплощены; длина створки составляет $4 / 5$ наибольшей ее ширины. Макушка небольшая, загнутая. Арея высокая, слабо вогнутая, апсаклинная. У одной створки высота ареи составляет $1 / 6$ ее длины. Дельтирий треугольный, открытый. Внутреннее строение створки неизвестно.

Спинная створка менее выпуклая, чем брюшная. Синус мелкий, прослеживается только в задней части створки. Макушка незаметная. Арея низкая, сильно анаклинная до ортоклинной. Нототирий широкий, треугольный, открытый. Брахиофоры короткие, угол между их вентральными частями около $90^{\circ}$. Нототириальная полость широкая, с дном в виде низкой платформы, передняя часть которой переходит в короткую и низкую срединную септу. Замочный отросток низкий, килеобразный. Аддукторное поле неразличимое. Дно створки гладкое, по краям ребристое.

Раковинное вещество непористое.

Размеры, мм:

\begin{tabular}{l|c|c|c}
\hline & Длина бр. ств. & Длина сп. ств. & Ширнна \\
\hline Целый экземпляр Вr. 103278 & 9,9 & 9,4 & около 11 \\
Спинная створка Вr. 103279 & - & около 10 & - \\
И з м ен ч и в о с т ь вида известна плохо. Изученный материал позво- \\
ляет заключить, что очертание раковины изменяется в ходе роста от \\
полуовального (у молодых экземпляров) \\
экземпляров).
\end{tabular}

5 ENSV TA Toimetised $\mathrm{K} * \mathrm{G}-31973$ 
С равнение и замечания. От наиболее сходных с ним североамериканских видов Taphrorthis emarginata Cooper и $T$. peculiaris Cooper (Cooper, 1956, с. 327-329) новый вид отличается меньшей выпуклостью створок, более высокой ареей брюшной створки и менее четкой поперечной струйчатостью. От видов Taphrorthis aff. peculiaris и $T$. aspera Williams из Шотландии (Williams, 1962, с. 102 и 103) T. dalarnaensis отличается меньшими размерами раковины и более тонкой ребристостью.

Taphrorthis dalarnaensis из макроурусового известняка (=низы верхнего карадока) Швеции является наиболее молодым известным представителем рода Taphrorthis (см. Cooper, 1956, с. 327 и 328; Williams, 1962 , с. $102-104)$. По стратиграфическому положению к новому виду наиболее близок шотландский вид Taphrorthis bellatrix (Reed) из свиты Баклачи (см. Williams, 1962, с. 104), который четко отличается от $T$. dalarnaensis значительно бо́льшими размерами раковины, большей выпуклостью створок и субквадратным очертанием раковины.

Р асп р остранени е. Макроурусовый известняк (s. 1.) Швеции.

Мес т он ах ж ден и е. Даларна, Фьяка, обнажение № $9 ; 1,5-1,6 \mathrm{~s}$ ниже верхней границы макроурусового известняка - 1 цел. экз.; 2,2$2,3 м$ ниже той же границы - 1 сп. ств.; $2,5-3,0$ м ниже той же границы - 1 фрагмент бр. ств.; $3,4-3,5$ м ниже той же границы -1 цел. экз.

\section{Семейство Plectorthidae Schuchert et LeVene, 1929}

\section{Подсемейство Rhactorthinae Williams, 1963}

\section{Род Rhactorthis Williams, 1963}

\section{Rhactorthis kaagverensis sp. nov.}

(Табл. I, фиг. $7-20$ )

Голоти п. Брюшная створка $\mathrm{Br} 4190$, табл. I, фиг. 7-9. Оандуский горизонт (DIII), Юго-Восточная Әстония, скв. Карула, гл. 399,2 м.

Д и агноз. Раковина субквадратного очертания, слегка вытянута в ширину. Мускульное поле брюшной створки треугольное, отпечатки аддукторов и дидукторов одинаковой длины. Vascula media pacходящиеся. На расстоянии 2 мм от макушки спинной створки в 2 мм насчитывается 7-8 ребрышек.

О п и с а и е. Раковина двояковыпуклая, с более выпуклой брюшной створкой. Очертание субквадратное, слегка вытянутое в ширину. Замочная линия прямая, соответствует или несколько короче наибольшей ширины рақовины. Замочные углы прямые. Передняя комиссура слабо сулькатная.

Раковина покрыта тонкими расщепляющимися ребрышками с грубой поперечной струйчатостью. Общее число ребрышек по краям раковины достигает 45, среди них 8-10 первичных. На расстоянии 2 и 5 мм от макушки спинной створки в 2 мм насчитывается соответственно $7-8$ и 6-7 ребрышек. Линии нарастания частые и резкие.

Брюшная створка умеренно выпуклая, с наивысшей точкой в задней части. Макушка маленькая. Арея длинная, слабо вогнутая в подмакушечной части, анаклинная; высота ареи составляет $1 / 10$ ее длины. Дельтирий треугольный, открытый. Зубы маленькие, с короткими зубными пластинами. Мускульное поле треугольное, длина его составляет $1 / 3$ длины 
створки. Отпечатки дидукторов узкие, аддукторов - широкие. Vascula media расходящиеся, разветвляются на передней половине створки. Линии нарастания поздних стадий роста выражены на дне створки в виде низких валиков, субпараллельных краям створки. Дно створки по краям ребристое.

Спинная створка слабо выпуклая; синус неглубокий, широкий. Макушка маленькая. Арея низкая, плоская, анаклинная. Брахиофоры тонкие, пластинчатые; раковинное вещество, соединяющее брахиофоры с задней частью створки, образует дно зубных ямок, приподнятое над дном створки. Утолщения брахиофор со стороны нототириальной полости развиты слабо. Замочный отросток имеет зубчатый миофор и широкий ствол, переходящий в срединную септу. Аддукторное поле выражено слабо. Дно створки гладкое, с концентрическими валиками, подобными валикам на дне брюшной створки; краевая ребристость четкая.

Раковинное вещество непористое.

Размеры, мм:

\begin{tabular}{l|l|l|}
\hline Длина бр. ств. $\mid$ Длина сп. ств. $\mid$ Ширина \\
\hline
\end{tabular}

Спинная створка $\mathrm{Br} 4188$

Целый экземпляр $\mathrm{Br} 4189$

Брюшная створка $\mathrm{Br} 4190$

Спинная створка $\mathrm{Br} 4191$ $-,-, \quad \mathrm{Br} 4194$

$\begin{array}{rcc}\text { - } & \text { оволо } 9 & \text { около } 10 \\ 6,9 & 6,9 & 7,7 \\ 10,1 & - & 12,0 \\ - & 8,8 & 10,7 \\ - & - & 8,4\end{array}$

С ра внение. От наиболее сходного с ним вида Rhactorthis crassa Williams (Williams, 1963, с. 372-375), из карадока Англии новый вид отличается треугольным очертанием мускульного поля брюшной створки и более расходящимися vascula media, менее развитой срединной септой и, возможно, менее расходящимися брахиофорами.

Rhactorthis kaagverensis имеет по форме раковины и характеру расщепления ребрышек большое сходство с представителями рода Рaucicrura из идавереского горизонта $\left(\mathrm{C}_{\mathrm{III}}\right)$ Прибалтики, но отличается от них четкой поперечной струйчатостью, внутренним строением створок и непористой структурой раковинного вещества.

Р аспространени е. Кейлаский (DII) и оандуский (D $\mathrm{D}_{\mathrm{III}}$ ) горизонты Юго-Восточной Эстонии, оандуский горизонт Южной Литвы.

M естон ахождени е. $\quad \mathbf{D}_{\text {II }}$ : скв. Каагвере, гл. 270,4-270,5 м 1 пп. ств.; D 220,25-220,35 $м-1$ фрагмент бр. ств.; скв. Каагвере, гл. 262,1 $м-1$ цел. экз,; 262,4-262,6 м-1 цел. экз.; скв. Карула, гл. $399,2 м-2$ бр. ств.; скв. Паявонис-13, гл. 1190,5-1190,6 м- 1 сп. ств., 1191,0-1191,05 $\mu-$ 1 цел. экз.; 1191,9-1192,0 $м-2$ сп. ств.; 1192,4-1192,5 $\mu-1$ цел. экз.

\section{Семейство Cremnorthidae Williams, 1963}

Род Septorthis gen. nov.

Ти п рода. Septorthis engurensis gen. et sp. nov.

Ди агноз. Раковина средних размеров. Замочный отросток килеобразный или двухлопастный. Брахиофоры расходятся в сторону заднего края створки, почти параллельны плоскости ареи.

О пи с ан ие. См. описание типового вида. 
С равнен ие. Новый род характеризуется признаками, свойственными роду Cremnorthis Williams, 1963 (подсемейства Cremnorthinae Williams, 1963), с одной стороны, и роду Phragmorthis Cooper, 1956 (подсемейства Phragmorthinae Williams, 1965), с другой стороны. Род Septorthis весьма сходен с первым по внешним признакам раковины и по расположению брахиофор (расходятся в сторону заднего края створки), но отличается от него низким килеобразным или двухлопастным замочным отростком и наличием своеобразных лопастных структур (иногда в виде низких платформ) у передней части кардиналия (см. рис. 2). Эти структуры в некоторых аспектах сходны с дорзальными частями брахиофор, соединяющимися со срединной септой и образующими подобную круралию структуру, у рода Phragmorthis (см. Williams, Rowell, 1965, рис. 131, A). Отмеченные лопастные образования развиты у рода Septorthis в виде «сидящего круралия». Роды Septorthis и Phragmorthis более всего сходны формой замочного отростка, но четко различаются по внешним признакам раковины. Все три рассматриваемых рода сходны внутренним строением брюшной створки. Они имеют небольшие массивные зубы и короткое субтреугольное мускульное поле.

Сравнение изученных прибалтийских представителей кремнортид с таковыми из Северной Америки и Англии дает основание считать, что различия между родами Phragmorthis, Cremnorthis и Septorthis имеют прежде всего родовое значение и выделение подсемейств в семействе Cremnorthidae не оправдано.

Septorthis engurensis gen. et sp. nov.

(Табл. ІІ, фиг. $1-21$, рис. 2)

Г ол о т и п. Спинная створка $\mathrm{Br} 4107$, табл. II, фиг. 6--8. Идавереский горизонт $\left(\mathrm{C}_{\mathrm{III}}\right)$, Западная Латвия, скв. Стури, гл. 1028,45 м.

Д и а г о з. Раковина небольших размеров, полуовального очертания. Высокая срединная септа доходит до передней половины спинной створки. На расстоянии 2 мм от макушки спинной створки в 2 мм насчитывается 6-8 ребрышек.

О пи с ан и е. Раковина небольших размеров, двояковыпуклая, с более выпуклой брюшной створкой. Очертание полуовальное, вытянутое в

\section{ТАБЛИЦА I}

Фит. 1-6. Taphrorthis dalarnaensis sp. nov. $1-4-$ раковина $\mathrm{Br}$. 103278, голот'чп, макро урусовый известняк, Швеция, Фьяка, обнажение № 9 (1,5-1,6 м ниже верхней границы макроурусового известняка); вид со стороны брюшной и спинной створок, сбоку и сзади; 5 и 6 - спинная створка $\mathrm{Br}$. 103279, макроурусовый известняк, Швеция, Фьяка, обнажение № 9 (2,2-2,3 $м$ ниже верхней границы); соответственно внешний вид и внутреннее строение. Увеличение $\times 3,5$.

Фиг, 7-20. Rhactorthis kaagverensis sp. nov. 7-9- брюшная створка Вг 4190, голотип, скв. Карула, гл. 399,2 м, DIII; внешний вид и внутреннее строение, вид сбоку. 10 - внутреннее строение спинной створки $\mathrm{Br} 4191$, скв. Паявонис-13, гл. 1190,51190,6 м, D $\mathrm{III} .11-13$ - спинная створка $\mathrm{Br} 4188$, скв. Каагвере, гл. 270,4-270,5 м, DII; внутреннее строение, внешний вид и вид с антеровентральной стороны. $14-17-$ раковина $\mathrm{Br} 4189$, скв. Каагвере, гл. 262,4-262,6 м, D спинной створок, сбоку и сзади. 18-20 - спинная створка Вr. 4194, скв. Паявонис-13, гл. 1191,9-1192,0 м, D III; внешний вид, внутреннее строение и вид с антеровентральной стороны.

Увеличения: фиг. $7-10-\times 3,3$; фиг. $11-13-\times 4,5$; фиг. $14-17-\times 4$; фиг. 18$20-\times 4,4$. 

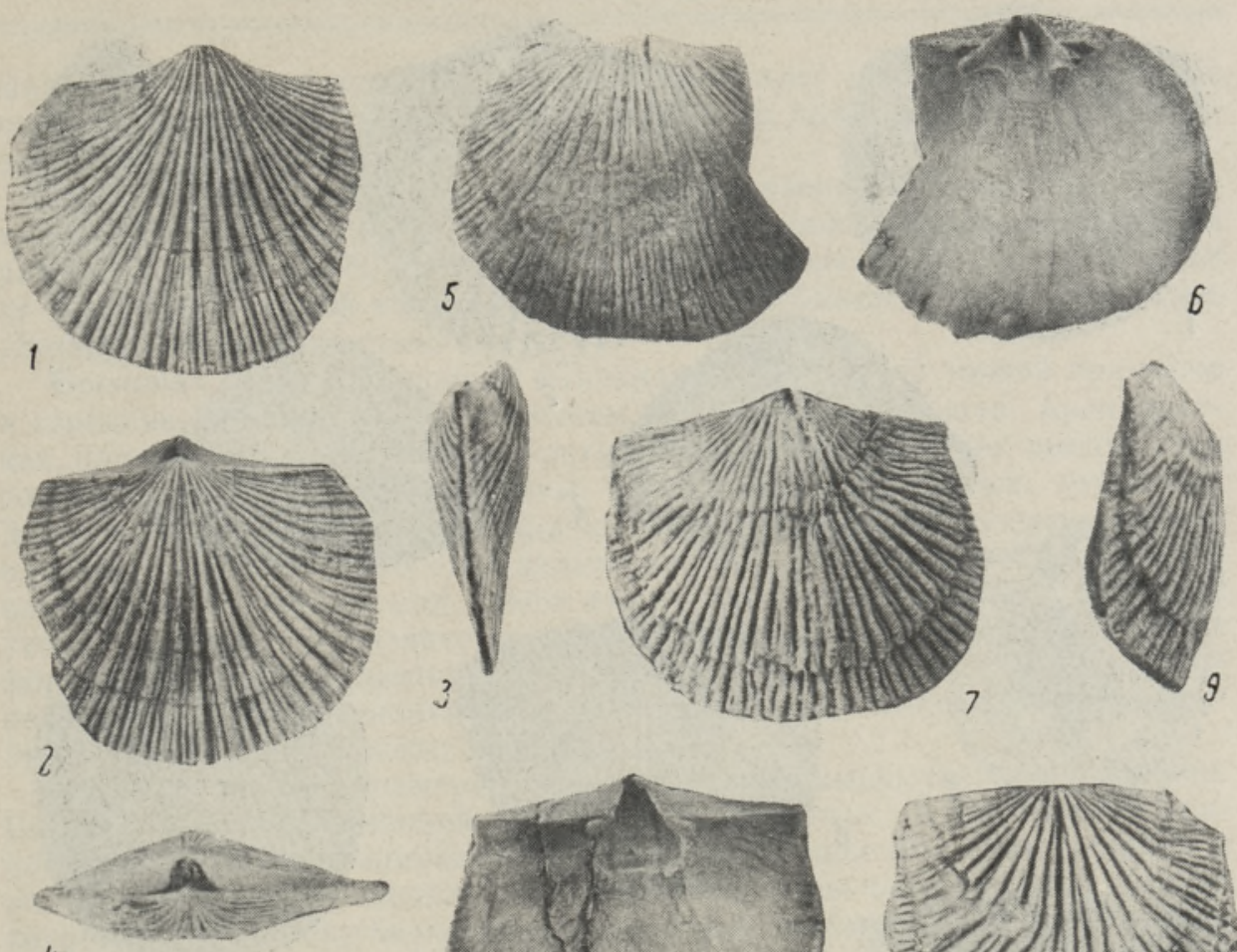

4.
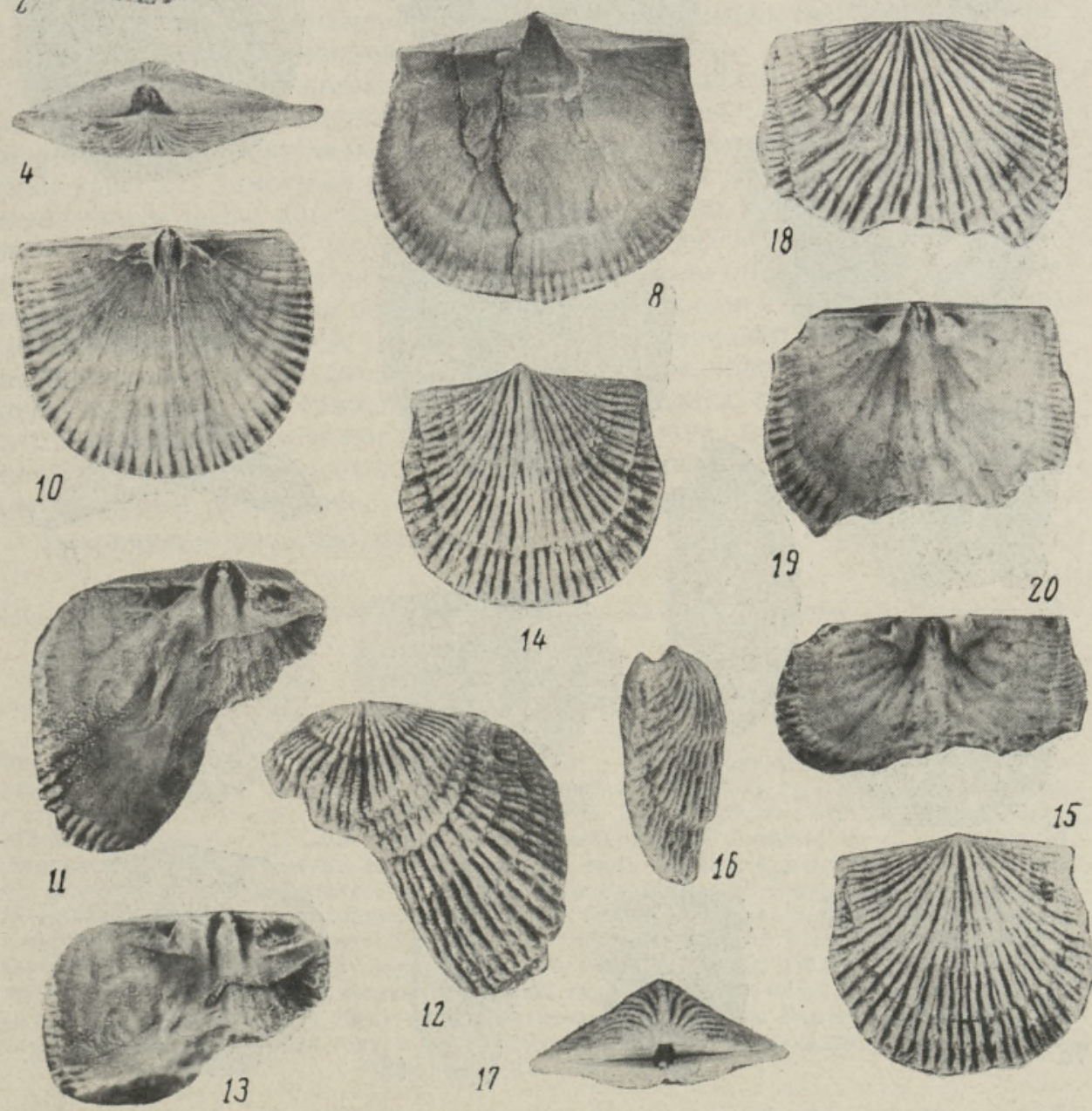

15
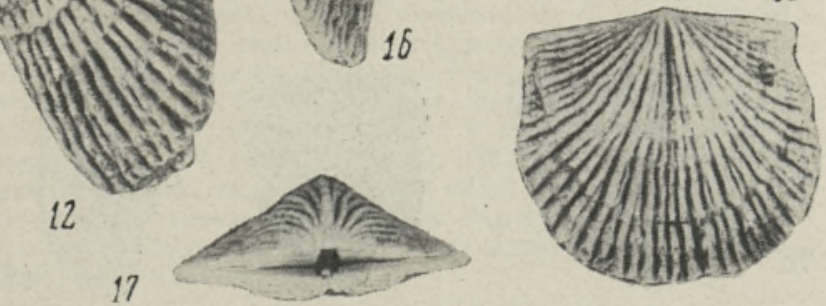

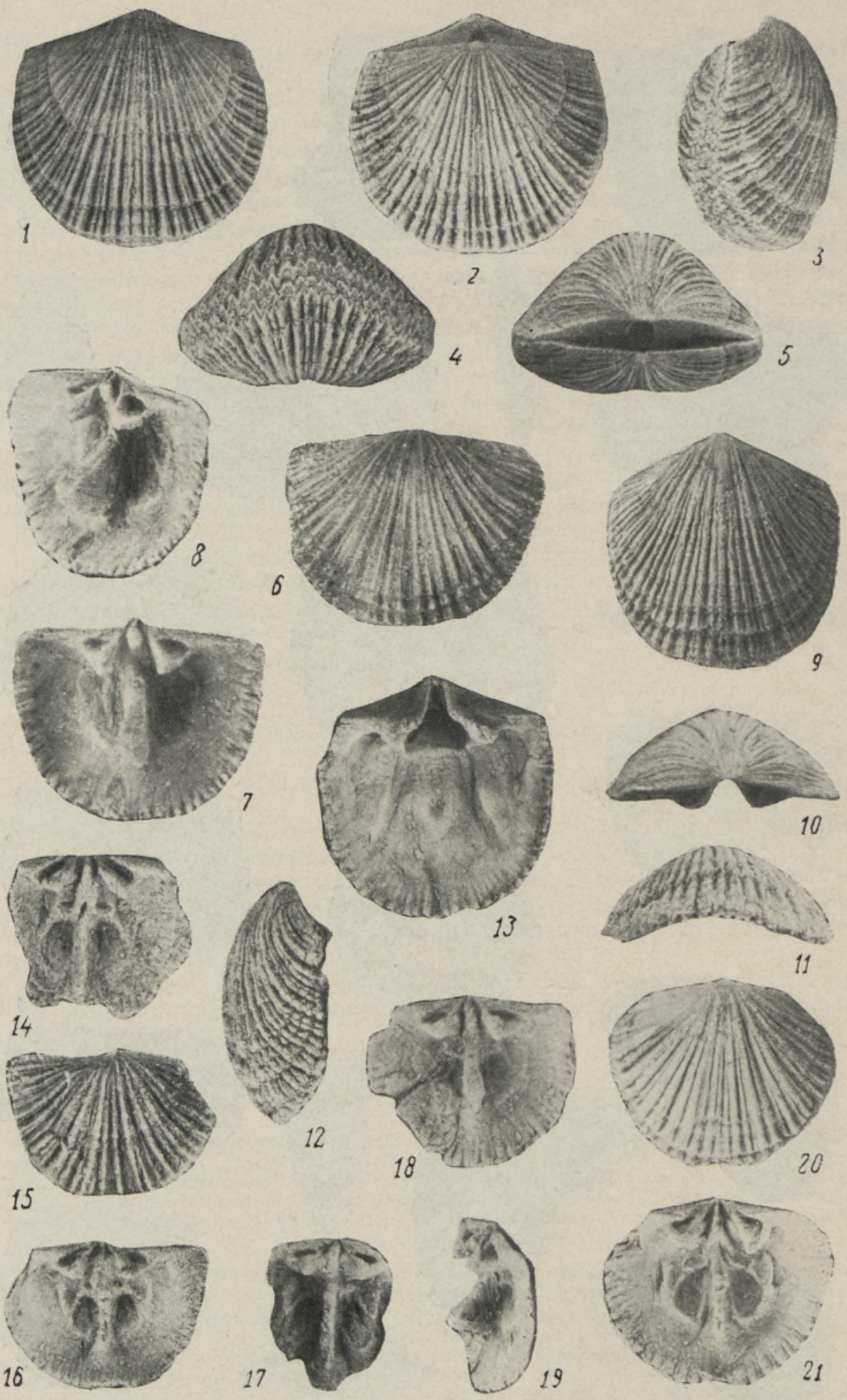
ширину. Замочная линия прямая, соответствует или несколько короче наибольшей ширины раковины. Замочные углы прямые или тупые. Передняя комиссура сулькатная.

Раковина покрыта тонкими ребрышками, увеличивающимися в числе путем расщепления и вклинивания. Общее число ребрышек по краям раковины достигает 50, среди них 8-9 первичных. На расстоянии 2 мм от макушки спинной створки в 2 мм насчитывается 6-8 ребрышек. Линии нарастания частые.

Брюшная створка умеренно выпуклая, с наивысшей точкой примерно в середине, боковые части уплощены. Макушка небольшая. Арея высокая, плоская, в подмакушечной части вогнутая, апсаклинная; высота ареи составляет в среднем $1 / 4$ ее длины. Дельтирий треугольный, открытый. Зубы короткие, утолщены вторичным раковинным веществом; зубные пластины развиты слабо. Дно дельтириальной полости имеет вид низкой платформы с прямым или слабо изогнутым передним краем. Ножное утолщение хорошо развито в виде трапециедальной маленькой платформы. Отпечатки дидукторов и аддукторов неразличимы. Vascula media расходящиеся. Дно створки по краям ребристое, утолщено между васкулярными сосудами и около замочных углов.

Спинная створка примерно в два раза менее выпуклая, чем брюшная. Синус неглубокий, широкий. Макушка незаметная. Арея низкая, анаклинная. Нототирий широкий, треугольный; вторичная арея развита в виде маленьких треугольных пластин. Брахиофоры пластинчатые, широко расходятся в сторону заднего края створки и окаймляют большие зубные ямки (рис. 2). Замочный отросток килеобразный или двухлопастный, не поднимается выше плоскости ареи. Дно передней части нототириальной полости и дорзальные части брахиофор переходят в лопастные образования, развитые иногда в виде низких платформ по обе стороны срединной септы. Срединная септа высокая, достигает передней половины створки; гребень септы в задней части изогнутый, в передней - почти прямой, перпендикулярный ко дну створки. Мускульное поле большое, занимает почти половину дна створки. Оппечатки передних аддукторов большие, субтреугольные; отпечатки задних - небольшие, треугольные, расположены постеролатерально по отношению к передним. Дно створки гладкое, по краям ребристое.

Раковинное вещество непористое.

\section{ТАБЛИЦА II}

Фиг. 1-21. Septorthis engurensis gen. et sp. nov. $1-5-$ раковина $\mathrm{Br} 4106$, скв. Кандава-25, гл. 927,5 м, DI; вид со стороны брюшной и спинной створок, сбоку, спереди и сзади. 6-8-спинная створка $\mathrm{Br} 4107$, голотип, скв. Стури, гл. 1028,45 м, Сіп; внешннй вид, внутреннее строение и вид с вентролатеральной стороны. $9-12$ - брюшная

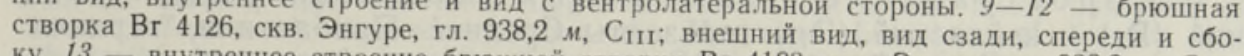
ку. 13 - внутреннее строение брюшной створки $\mathrm{Br} 4103$; скв. Энгуре, гл. 938,2 $\mu, \mathrm{C}_{\mathrm{III}}$; 14 - внутреннее строение спинной створки $\mathrm{Br}$. 103280, Швеция, Фьяка, обнажение № 8 , известняк Далбю (1,55 м ниже комплекса метабентонитов); 15 и 16 - внешний вид и внутреннее строение спинной створки $\mathrm{Br} 4102$, скв. Энгуре, гл. 938,3 м, СІг; 17 - внутреннее строение спинной створки $\mathrm{Br} 4104-\mathrm{B}$, скв. Энгуре, гл. 938,2 м, СІІ; 18 и $19-$ внутреннее строение и вид сбоку спинной створки $\mathrm{Br} 4125$, скв. Ремте, гл. $1043-1045$ м, $\mathrm{C}_{\mathrm{III}} ; 20$ и 21 - внешний вид и внутреннее строение спинной створки $\mathrm{Br} 4105$, скв. Ремте, гл. $1043-1045$ м, С III. $_{\text {. }}$.

Увеличения: фиг. $1-8$, фиг. $14-\times 7,6$; фиг. $9-13-\times 7,7$; фиг. $15,16-\times 7,1$; фиг. $17-\times 10$; фиг. $18,19-\times 8$; фиг. $20,21-\times 7,9$. 

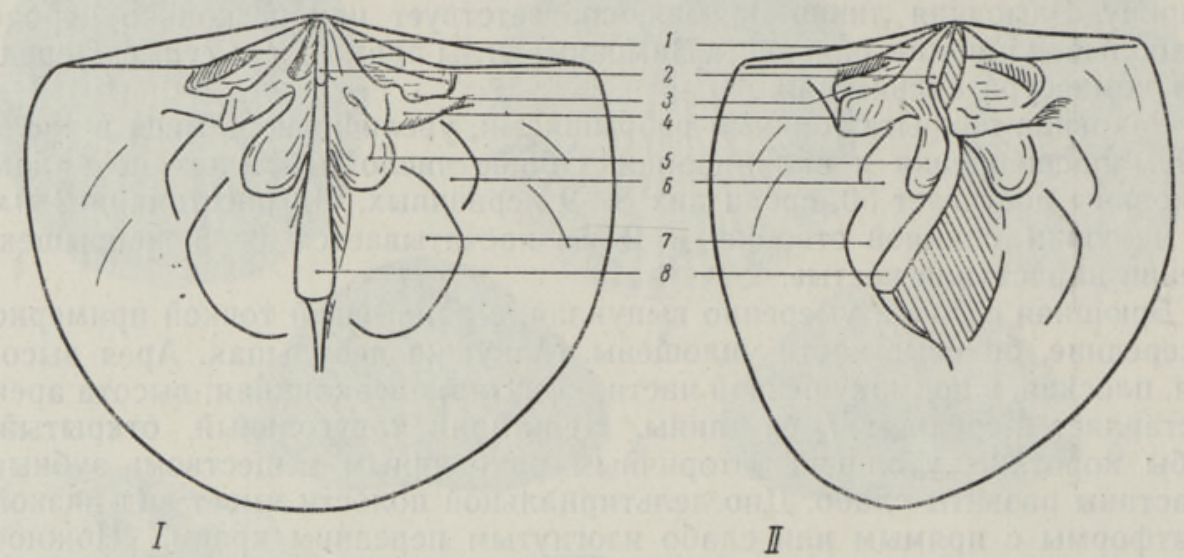

Рис. 2. Схема внутреннего строения спинной створки Septorthis engurensis gen. et sp. nov. I и II - вид с вентральной и вентролатеральной сторон.

1 - вторнчная арея; 2 - замочный отросток; 3 - зубные ямки; 4 - 6рахиофоры, расходящнеся в сторону заднего края створки; 5 - лопастные образования у передней части кардиналия (๔сндящий круралий»); 6 - отпечатки задних аддукторов; 7 отпечатки передних аддукторов; 8 - срединная септа.

Размеры, мм:

$\mid$ Длина бр. ств. $\mid$ Длина сп. ств. $\mid$ Ширина

Спинная створка $\mathrm{Br} 4102$ Брюшная створка $\mathrm{Br} 4103$ Спинная створка $\mathrm{Br} 4105$ Целый экземпляр $\mathrm{Br} 4106$ Спинная створка $\mathrm{Br} 4107$

$$
\begin{array}{lc}
-,-, & \mathrm{Br} .103280 \\
-,- & \mathrm{Br} 4125
\end{array}
$$

Брюшная створка $\mathrm{Br} 4126$

$\begin{array}{rrr}\overline{4,8} & 2,8 & 4,2 \\ \overline{-} & - & 4,5 \\ 4,7 & 3,5 & 4,4 \\ - & 4,0 & 5,0 \\ - & 3,9 & 5,0 \\ \overline{-} & \text { около } 3,2 & -\overline{2} \\ 4,6 & 3,3 & 4,6\end{array}$

Из мен ч и вость. Описанный вид в отношении внешних признаков раковины и особенно внутреннего строения брюшной створки малоизменчив. Более изменчивым является внутреннее строение спинной створки. Очертание аддукторного поля варьируется от овального до субтреугольного, в некоторых случаях оно вообще слабо выражено. Структуры, образующие «сидящий круралий» варьируются от длинных лопастных образований (см. табл. II, фиг. 17 и 23) до коротких, слабо выраженных структур в виде низких платформ (см. табл. II, фиг. 18). Подавляющая часть спинных створок характеризуется килеобразным замочным отростком, но у некоторых створок замочный отросток толстый, двухлопастный.

$\mathrm{P}$ асп постранен ие и за меч ания. Идавереский $\left(\mathrm{C}_{\text {III }}\right)$, йыхвиский $\left(\mathrm{D}_{\mathrm{I}}\right)$ и кейлаский $\left(\mathrm{D}_{\mathrm{II}}\right)$ горизонты Средней Прибалтики, верхняя половина известняка Далбю в Швеции.

В разрезах Западной Латвии Septorthis engurensis появляется совместно с одним мелким далманеллидом (вид еще не описан) и представителями родов Eoplectodonta и Leiosphaeridia (крупные формы) на уровне, грубо соответствующем нижней границе идавереского горизонта. Возможно, что этот род представлен еще в Юго-Восточной Эстонии, однако найденные там единичные экземпляры, которые более сходны с представителями рода Septorthis, чем рода Cremnorthis, точнее не идентифицируемы из-за плохой сохранности. 
Местонахождени е. $\mathbf{C}_{\text {III: }}$ скв. Ремте, гл. 1043-1045 $\mu-18$ бр. ств., 11 сп. ств.; скв. Энгуре, гл. 938,2 $м-3$ бр. ств., 938,3 $\mu-2$ цел. экз., 1 бр. ств., 6 сп. ств.; 938,5 $\mu-3$ бр. ств.; скв. Адзе, гл. 889,4 $\mu-$

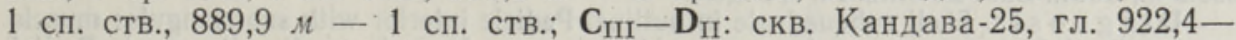
$923,3 \mu-5$ сп. ств., 3 бр. ств., 927,5-929,7 $и-10$ цел. экз., 20 бр. ств., 25 сп. ств.; Фьяка, обнажение № 8, 1,55 $м$ ниже подошвы комплекса метабентонитов - 2 сп. ств.; $3,28-3,30$ м ниже того же уровня -1 сп. ств.

\section{ЛИТЕРАТУРА}

Мянниль Р. M. 1963. Биостратиграфическое обоснование расчленения ордовикских отложений Западной Латвии. Тр. Ин-та геол. АН ЭССР, XIII.

Мянниль Р. М. 1966. История развития Балтийского бассейна в ордовике. Таллин. $\mathrm{J}$ a a nuss on V., Martna J. 1948. A section from the Upper Chasmops series to the Lower Tretaspis series at Fjäcka rivulet in the Siljan area, Dalarna. Bull. Geol. Inst. Uppsala, XXXII.

Co op er G. A. 1956. Chazyan and related Brachiopods. Smiths. Misc. Coll., 127.

Williams A. 1962. The Barr and Lower Ardmillian Series (Caradoc) of the Girvan District, South-west Ayrshire, with description of the Brachiopods. Mem. Geol. Soc. London, 3.

Williams A. 1963. The Caradocian Brachiopod Faunas of the Bala District, Merionethshire. Bull. Brit. Mus. (Nat. Hist.) Geol., 8, No. 7.

Williams A., Rowell A. 1965. Morphology. in: Treatise on Invertebrate Paleontology. Part H. Brachiopoda, 1.

Williams A., Wright A. 1965. Orthidae. in: Treatise on Invertebrate Paleontology. Part H, Brachiopoda, 1.

$\begin{array}{cc}\text { Институт геологии } & \text { Поступила в редакцию } \\ \text { Академии наук Эстонской ССР } & 6 / \text { III } 1973\end{array}$

\section{LINDA HINTS}

\section{ORTHACEA UUED BRAHHIOPOODID BALTIKUMI JA ROOTSI KESKORDOVIITSIUMIST}

Artiklis kirjeldatakse ülemsugukonna Orthacea uut perekonda Septorthis't ja uusi liike Septorthis engurensis't idavere, jōhvi ja keila lademest, Rhactorthis kaagverensis't keila ja oandu lademest ning Taphrorthis dalarnaensis't Rootsi Macrourus-lubjakivist.

\section{LINDA HINTS}

\section{NEW ORTHACEAN BRACHIOPODS FROM THE MIDDLE ORDOVICIAN OF THE EAST BALTIC AREA AND SWEDEN}

A description of the new genus Septorthis and new species Septorthis engurensis from the Idavere, Jõhvi and Keila Stages of Western Latvia and Dalby Limestone of Sweden, Taphrorthis dalarnaensis from the Macrourus Limestone of Sweden and Rhactorthis kaagverensis from the Keila and Oandu Stages of Southern Estonia and Lithuania is presented. Septorthis engurensis appears at the stratigraphical level which seems to correspond to the lower boundary of the Idavere Stage.

Taphrorthis dalarnaensis sp. nov.

H o lot y pe. Complete shell Br. 103278, Macrourus Limestone, Fjäcka, loc. 9, Sweden. Pl. I, Figs. $1-4$.

Diagnosis. Shell of gently convex valves, with pedicle valve about $4 / 5$ as long as wide. Pedicle interarea high. Radial ornamentation consisting of up to 62 costae and costellae, with modal count of 4 and 8 per $2 \mathrm{~mm}$, in 2 and $5 \mathrm{~mm}$ from the dorsal umbo. 
Rhactorthis kaagverensis sp. nov.

Hol otype. Pedicle valve $\mathrm{Br} 4190$, Blidene Beds $\left(D_{111} B\right)$, Karula boring, depth $399.2 \mathrm{~m}$, South-East Estonia. Pl. I, Figs. 7-9.

$\mathrm{D} \mathrm{i}$ a $\mathrm{n}$ o s i s. Shell subquadrate in outline. Pedicle interior with subtriangular muscle scar, with diductor scars as long as adductor scar. Vascula media divergent. Radial ornamentation consisting of 7 to 8 costae and costellae per $2 \mathrm{~mm}$, at $2 \mathrm{~mm}$ anterior of dorsal umbo.

\section{Genus Septorthis gen. nov.}

Ty pe species. Septorthis engurensis gen. et sp. nov.

$\mathrm{Di}$ a $\mathrm{g}$ n o s is. Cremnorthidae of moderate size. Cardinalia consisting of narrow or bilobed cardinal process, continuous with high, blade-like median septum, subtriangular in outline, and divergent brachiophores with bases curved laterally to define a pair of sockets.

Septorthis engurensis gen. et sp. nov.

Hol ot y pe. Brachial valve $\mathrm{Br} 4107$, Idavere Stage $\left(\mathrm{C}_{111}\right)$, Sturi boring, depth $1028.45 \mathrm{~m}$, West-Latvia. Pl. II, Figs. 6-8.

Di a g r o sis. Shell of moderate size, suboval in outline. Dorsal median septum extends to anterior half of valve. Radial ornamentation consisting of fine costellae varying from 6 to 8 per $2 \mathrm{~mm}$, at $2 \mathrm{~mm}$ anterior of dorsal umbo. 